\title{
LETTER
}

\section{Site-selected Mutagenesis of the Drosophila Second Chromosome via Plasmid Rescue of Lethal P-element Insertions}

\author{
Yiquan Guo, ${ }^{1}$ Ann Gillan, ${ }^{1}$ Tibor Török, ${ }^{2}$ Istvan Kiss, ${ }^{2}$ Julian A.T. Dow, ${ }^{1}$ \\ and Kim Kaiser ${ }^{1,3}$
}

\author{
${ }^{1}$ Division of Molecular Genetics, Institute of Biomedical and Life Sciences, University of Glasgow, \\ Glasgow G11 6NU, United Kingdom; ${ }^{2}$ Institute of Genetics, Biological Research Centre of the Hungarian \\ Academy of Sciences, H-6701 Szeged, Hungary
}

\begin{abstract}
This paper describes a fast and efficient approach to correlating cloned genes with mutant phenotypes in Drosophila. We make use of a large collection D. melanogaster lines with recessive lethal insertions of a P[lacM transposon on their second chromosome. Within this collection there clearly must be many insertions corresponding to Drosophila genes that have been cloned and characterized, e.g., via homology with cloned mammalian genes, but for which mutant phenotypes have yet to be identified. We have made use of the fact that $\mathrm{P}[\mathrm{lacW}$ contains a plasmid replicon to establish a collection of rescued plasmids containing genomic DNA flanking the sites of transposon insertion. Plasmids representing a total of 1836 lines were independently rescued and pooled in batches of 10 and 100 . Pools of 100 plasmids were screened by hybridization with cDNAs corresponding to cloned second chromosome loci. Hybridizing pools were then narrowed down to single plasmids by a process of subdivision and rehybridization, and corresponding mutant lines were obtained. The success rate was better than one in four. This rate would undoubtedly be improved by the use of genomic DNA probes.
\end{abstract}

Many cloned Drosophila genes have yet to be correlated with a mutant phenotype. Site-selected transposon mutagenesis (SSM) is a reverse genetics solution to this problem. As described originally it involves the use of PCR between geneand transposon-specific primers to identify individuals in which a P-element transposon had inserted in or close to a target gene (Ballinger and Benzer 1989; Kaiser and Goodwin 1990). The sensitivity of PCR allows a new insertion to be detected initially within a population of mutagenized flies, after which it can be followed, as a specific amplification product, while the population is subdivided. A similar strategy has been applied to mutagenesis of Caenorhabditis elegans (Rushforth et al. 1993; Zwaal et al. 1993) and maize (Das and Martienssen 1995).

$P$ elements engineered to contain a plasmid origin of replication and a drug-resistance determinant allow a different form of SSM, involving plasmid rescue of DNA flanking the site of inser-

${ }^{3}$ Corresponding author.

E-MAIL k.kaiser@udcf.gla.ac.uk; FAX 44-(141)-330-5994. tion (Fig. 1; Hamilton et al. 1991; Hamilton and Zinn 1994). Pools of plasmids are created, each representing a population of flies with different insertion sites. Hybridization between a pool and a specific cDNA/genomic DNA fragment is diagnostic of an insertion in or near the gene of interest. The relevant pool is then narrowed down to a single hybridizing plasmid, and thus to the corresponding Drosophila line, by a process of subdivision and rehybridization (Hamilton et al. 1991).

Generation of large numbers of P-element insertion lines is labor-intensive, as is their maintenance. In any case, only a small fraction of all new P-element insertions is associated with phenotypic consequences. Thus, SSM tends to involve relatively impermanent collections of lines that are discarded or dispersed soon after screening. Even allowing for simultaneous screening with a number of target genes, this tends to reduce the generality of SSM. Further, plasmid rescue SSM tends to be performed on pools of lines (Hamilton et al. 1991; K. Basler and E. Hafen, pers. comm.), rather limiting the amount of plas- 


\section{PLASMID RESCUE OF THE DROSOPHILA SECOND CHROMOSOME}

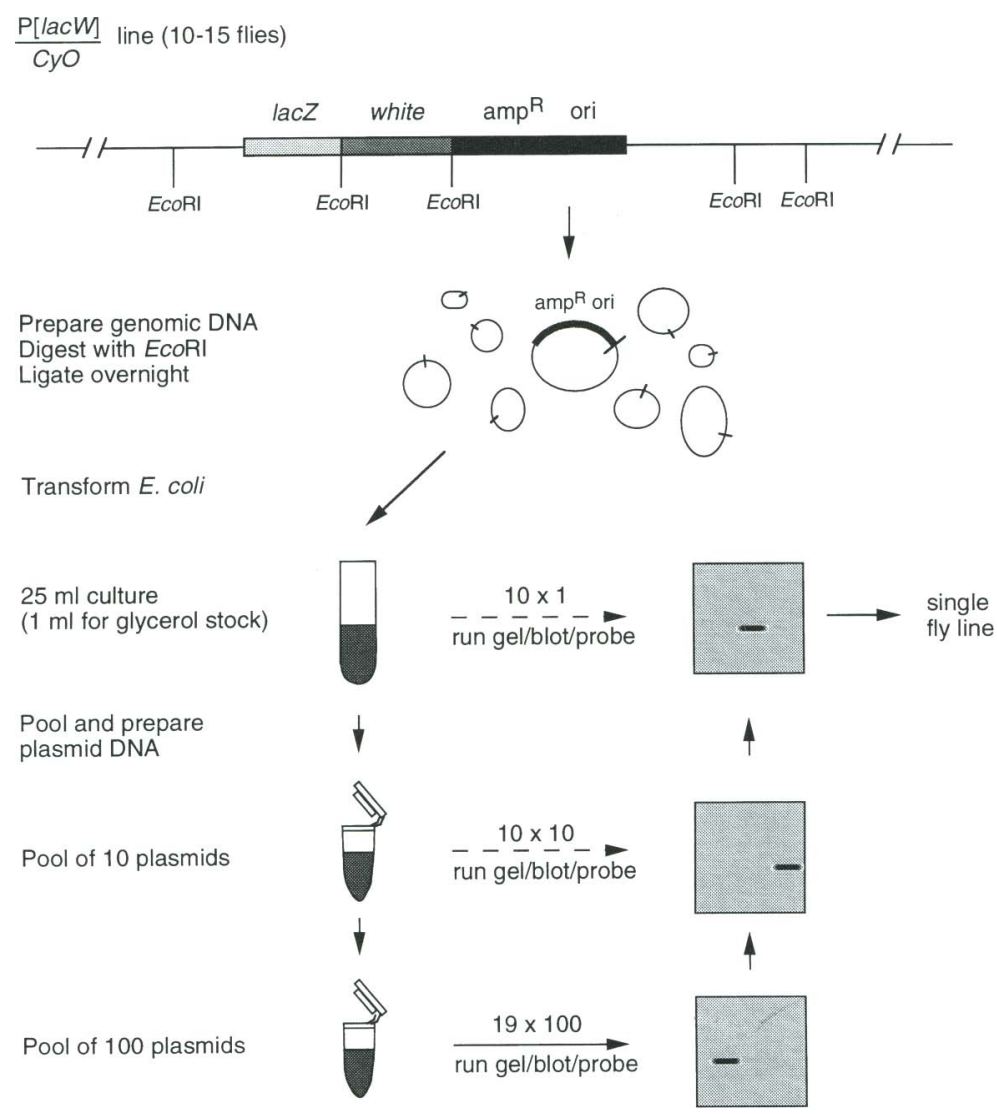

Figure 1 Overview of the plasmid rescue strategy. The essential structure of the $\mathrm{P}[\mathrm{lacW}]$ transposon is shown at top. Each line is maintained as a balanced lethal in which only one of the pair of second chromosomes carries a recessive lethal $\mathrm{P}[\mathrm{lacW}]$ insertion. The other second chromosome, the balancer $\mathrm{CyO}$, confers a dominant visible phenotype (curly wings), is homozygous lethal, and suppresses recombination. Balanced lethal lines are thus easily maintained, because viable progeny have the same chromosomal constitution as their parents (see Ashburner 1989). P[lacW contains an ampicillin resistance determinant $\left(a m p^{R}\right)$ and a plasmid origin of replication (ori). This plasmid replicon is separated from the rest of the transposon by a unique site for EcoRI. Rescued plasmids therefore contain DNA extending to the right of the transposon up to the nearest flanking EcoRI site (complete digestion), or to a more distant site (partial digestion). Full arrows in anticlockwise direction show the order in which particular steps were carried out. Dashed arrows show source of plasmid DNA for second and third rounds.

mid DNA that can be generated per individual line, and leading inevitably to misrepresentation of the individual plasmids. If time and resources allowed, it clearly would be preferable to rescue each line independently.

A recent large scale screen for $\mathrm{P}[\mathrm{lac} W]$ transposon insertions on the D. melanogaster second chromosome forms the background to a means by which some of the above problems can be overcome. 2308 independent recessive lethal mutations and 403 semi-lethal mutations were generated, each of which was saved in the form of a balanced lethal stock, and the lethal phase determined (Török et al. 1993). Pinduced lethals, though infrequent, almost by definition must correspond to insertions within genes. Inevitably, the collection is likely to include many examples of genes that have been hit more than once. There is also an unexpectedly high frequency $(-50 \%)$ of lethals that do not coincide with an inserted P element. Nevertheless, the collection represents a substantial proportion of the 2000 or so lethal complementation groups estimated to be present on the second chromosome [13/48 of the lethal complementation groups within the 1.8-Mb 34D-36A region, for example (Spradling et al. 1995)]. Moreover, even nonlethal insertions are useful starting points for the secondary mutagenesis of flanking loci. The lines will be maintained in Szeged (Hungary), and possibly in other stock centers, for the conceivable future.

\section{RESULTS}

\section{Plasmid Rescue}

$\mathrm{P}[\mathrm{lac} W]$, a modified P-element transposon $10.6 \mathrm{~kb}$ in length, was designed as an enhancer-trap element (Bier et al. 1989). It carries a lac $Z$ reporter gene, the eye-color marker white ${ }^{+}$, and a plasmid replicon with poly-linker (Fig. 1). Insertion within a Drosophila gene of such a large element might be expected often to have significant consequences for gene expression (Spradling et al. 1995). Plasmid rescue using the enzyme EcoRI was attempted independently for 2210 of the lines of Török et al. (1993), as described in Methods.

Independent rescue and transformation allowed each transformant to be propagated without the risk of competitive growth. Rescue was successful in the case of 1836 of the 2210 lines $(83 \%)$. Recalculated in the context of available in situ hybridization data, this corresponds to $77 \%$ rescue of lines containing a single $\mathrm{P}[\mathrm{lacW}]$ ele- 


\section{GUO ET AL.}

ment, and $89 \%$ rescue of lines containing more than one P[lacW] element. Because we were concerned that such a large series of transformations could present a contamination problem, smallscale plasmid preparations of at least 500 transformants were analyzed by agarose gel electrophoresis. Plasmid sizes varied considerably, with no evidence of contamination at any stage (not shown). Because most lines contain just one $\mathrm{P}[\mathrm{lac} W]$ transposon (data not shown; Török et al. 1993), rescue usually involved a single flanking region. Partial cleavage of genomic DNA by EcoRI can give rise to a series of related plasmids, however, and it is also possible for unrelated EcoRI fragments to be "co-cloned."

A $25-\mathrm{ml}$ culture was generated for each $\mathrm{P}[$ lacW $]$ line, and a small quantity was put into long-term storage in the form of a glycerol stock. The remainder was pooled together with cultures representing nine other lines, and plasmid DNA was isolated. Equal volume samples of 10 such plasmid preparations were then mixed to create effective pool sizes of 100 plasmids. The amount of plasmid DNA generated will be sufficient for many screenings.

\section{Screening}

Plasmid DNAs in each of the 19 pools of 100 plasmids are separated in 20-slot agarose gels (Fig. 2). The final slot is used for hybridization controls and size markers. To screen for an insertion in the

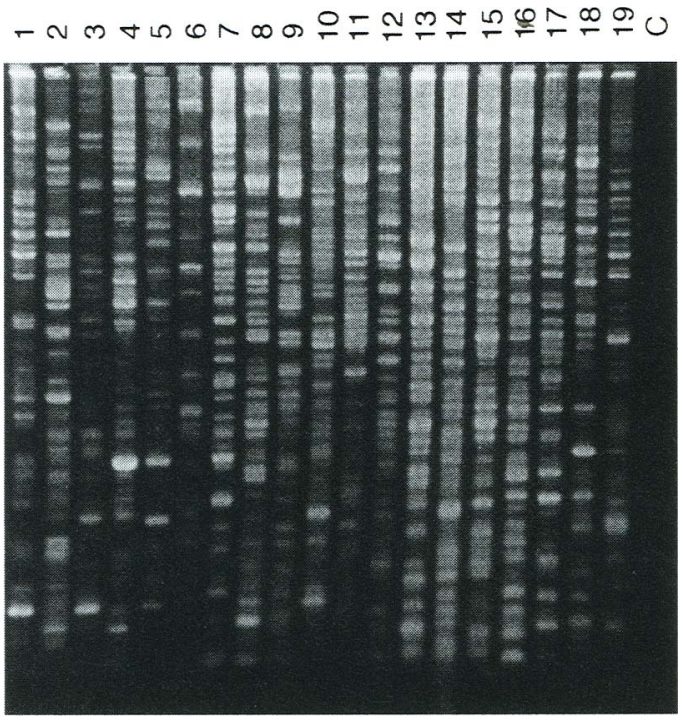

Figure 219 pools of 100 plasmids separated by electrophoresis in a $0.8 \%$ agarose gel. vicinity of a cloned gene, a blot of the gel is hybridized with a relevant cDNA or genomic DNA fragment. If the fragment has been cloned using a vector that contains plasmid sequences, it is essential that the fragment be gel-isolated before use. Here we show the results of screening with cDNA fragments representing the following genes: vha68-2, encoding subunit A of the Drosophila vacuolar ATPase (Fig. 3); ductin, encoding subunit c of the Drosophila V-ATPase (Finbow et al. 1994; Fig. 4); and DC0, encoding the catalytic subunit of cAMP-dependent protein kinase (Kalderon and Rubin 1988; Fig. 5). In case of vha68-2, for example, bands of hybridization are seen in three lanes of 100 plasmids. One such band was followed through subdivision to the relevant 10 batches of 10 plasmids, and was eventually narrowed down to a single glycerol stock (Fig. 3). A similar procedure was followed for the other two genes (Figs. 4,5).

As an alternative to screening pools of plasmids, we have used a one-step screening procedure involving grids of colonies created by a robotic device. The entire grid is visualized by hybridization with a ${ }^{35} \mathrm{~S}$ probe for the plasmid replicon, whereas individual colonies corresponding to particular insertion sites are visualized with a ${ }^{32} \mathrm{P}$ probe specific to the gene of interest (not shown). Automated production of

A - ผ

B

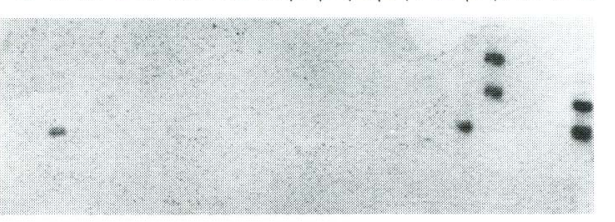
C C n m $\operatorname{con} \infty \pi \circ 0$
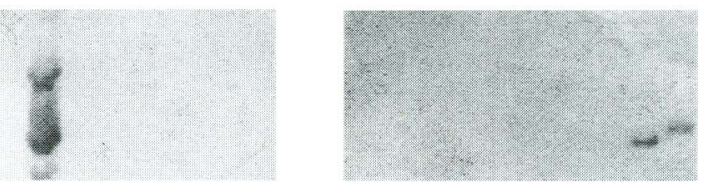

Figure 3 Screening for insertions in the gene encoding subunit A of the Drosophila V-ATPase. $(A)$ Three pools of 100 plasmids showed crosshybridization with a subunit A cDNA probe (lanes $2,16,17)$. (B) Screening the 10 pools of 10 plasmids corresponding to lane 2 further narrowed down this particular insertion (lane 3 ). (C) hybridization was assigned eventually to a plasmid isolated from a single glycerol stock (lane 10). C indicates a positive hybridization control (vha68-2 cDNA). 
A

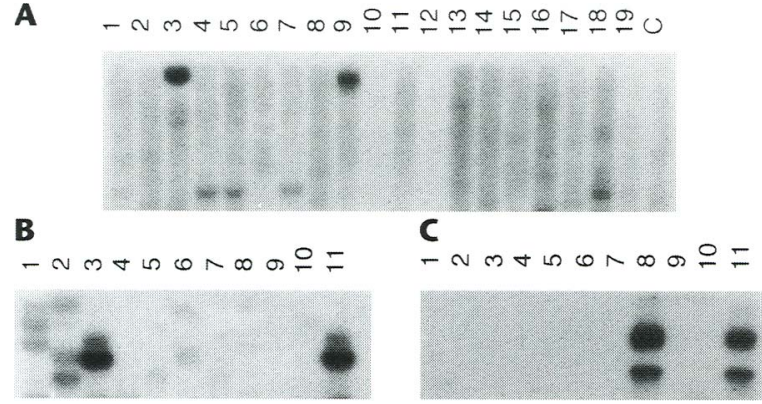

Figure 4 Screening for insertions in ductin, encoding subunit $\mathrm{c}$ of Drosophila V-ATPase. (A) Two pools of 100 plasmids showed cross-hybridization with a ductin CDNA probe (lanes 3,9). Lane $C$ did not contain a control for the ductin probe (blots are reused). (B) Screening the 10 pools of 10 plasmids corresponding to lane 3 further narrowed down this particular insertion (lane 3). Lane 11 represents the previous pool of 100. (C) Hybridization was assigned eventually to a plasmid isolated from a single glycerol stock (lane 8 ). Lane 11 represents the previous pool of ten.

grids would allow widespread distribution of filters for screening by other laboratories.

\section{Verification}

Once an individual glycerol stock has been identified as containing the hybridizing plasmid, the corresponding balanced lethal line is obtained from the stock collection in Szeged. At this stage it is crucial to verify that the plasmid and Drosophila line do indeed correspond. This can be done easily by repetition of plasmid rescue. In the case of the three insertions followed in Figures 3-5, plasmids of identical size and hybridization characteristics were indeed rescued (data not shown). Were some unrelated EcoRI fragment to have been co-cloned during the initial rescue, it is highly unlikely that the same event would occur a second time.

To confirm that each line contains only a single insertion of $\mathrm{P}[\mathrm{lacW}]$, we hybridize blots of mutant genomic DNA with a $\mathrm{P}[$ lac $W]$-specific probe. All three lines appeared to contain only one insertion (Fig. 6).

Other important concerns are whether the $\mathrm{P}$ element has indeed inserted within the target gene (a gene-specific probe may unexpectedly hybridize to other sites in the genome), and whether insertion is truly the cause of lethality. In the case of the gene for subunit A of the Dro-

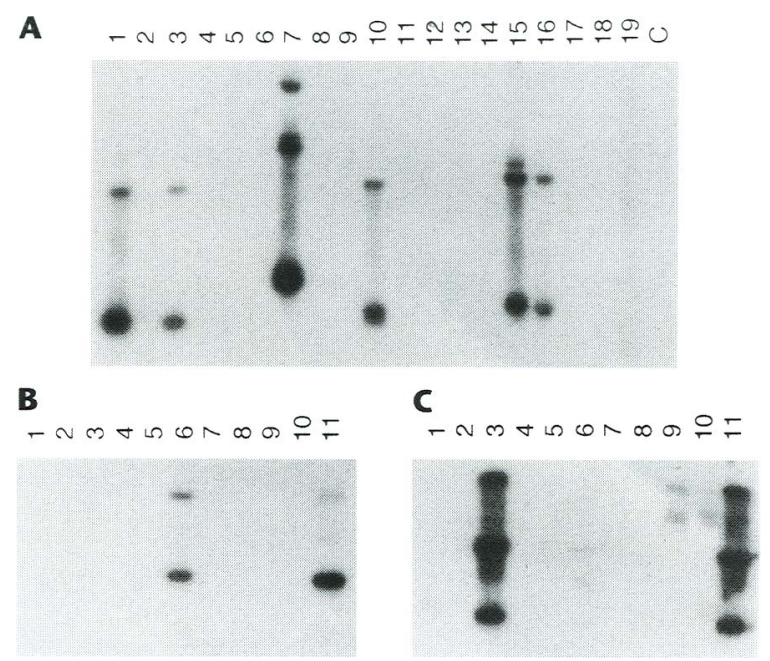

Figure 5 Screening for insertions in $D C 0$, encoding a catalytic subunit of CAMP-dependent protein kinase. (A) Several pools of 100 plasmids showed cross-hybridization with a DCO CDNA probe. Lane C did not contain a control for the $D C O$ probe (blots are reused). (B) Screening the 10 pools of 10 plasmids corresponding to lane 1 further narrowed down this particular insertion (lane 6). Lane 11 represents the previous pool of 100 . (C) Hybridization was assigned eventually to a plasmid isolated from a single glycerol stock (lane 3). Lane 11 represents the previous pool of ten.

sophila vacuolar ATPase, the rescued plasmid hybridized in situ to a single polytene chromosome band corresponding to the known location of the gene, and sequencing of the rescued plasmid showed insertion to have occurred in the first intron of the gene, $-0.5 \mathrm{~kb}$ in front of the translation start site (Fig. 7a). Transposase-induced loss of the insertion is associated with reversion of the lethality, which occurs during the first larval instar (Y. Guo, J.A.T. Dow, G. Tick, and K. Kaiser, unpubl.). The sites of $\mathrm{P}[\mathrm{lacW}]$ insertion in the other two lines are shown in Figure 7B,C. Note that many of the second chromosome insertions have now been mapped by in situ hybridization to polytene chromosomes (Spradling et al. 1995). Information is available via Flybase (http://morgan.harvard.edu/) and the Encyclopedia of Drosophila (http://shoofly.berkeley.edu/).

In total, 27 cDNA fragments corresponding to second chromosome genes have been used as probes. Positive hybridization signals were in seven cases shown to represent genuine insertions within or near to target genes (Table 1). In five of the seven cases, $\mathrm{P}[\mathrm{lacW}]$ insertion had oc- 
GUO ET AL.

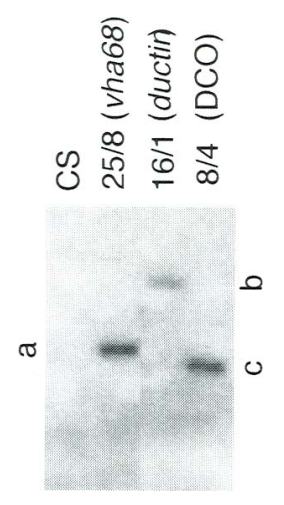

Figure 6 Southern blot of genomic DNA isolated from individuals heterozygous for each of the three insertions. Genomic DNA was cleaved with EcoRI, and hybridized with a $1.8-\mathrm{kb}$ fragment of $\mathrm{P}[\mathrm{lacW}]$ containing the plasmid replicon (Fig. 1). (Lane 1) Canton-S wild type; (lane 2) line $25 / 8$ having an insertion in vha68-2; (lane 3) line 16/1, having an insertion in ductin; (lane 4) line $8 / 4$, having an insertion in DCO. Each of the three lines displays evidence for only a single $\mathrm{P}[\mathrm{lacW}]$ insertion. Fragment sizes in kb are as follows: (a) 5.2; (b) 10.0; (c) 4.6. These correspond to the sizes expected from the rescued plasmids. The blot has been edited by precise removal of one irrelevant lane.

curred $5^{\prime}$ to the reported coding sequence. In the other two cases, it separated second and third exons. That $P$ elements prefer to insert near to the 5 ' ends of genes has been observed in other studies (Spradling et al. 1995).

\section{METHODS}

The Szeged lines are maintained as balanced lethals of the form P[lacW]/CyO (Fig. 1; Török et al. 1993). Genomic DNA was prepared by a modification of the method of Hamilton et al. (1991). Ten to fifteen flies from each line were homogenized with a motorized pestle in a microfuge tube in the presence of $400 \mu \mathrm{l}$ of lysis buffer [ $80 \mathrm{~mm} \mathrm{NaCl}$, $5 \%$ sucrose, $0.5 \%$ SDS, $50 \mathrm{~mm}$ EDTA, and $100 \mathrm{~mm}$ Tris- $\mathrm{HCl}$ (pH 8.5)]. Following $30 \mathrm{~min}$ at $70^{\circ} \mathrm{C}$, KOAc was added to a final concentration of $0.6 \mathrm{M}$, and the tube was placed on ice for $30 \mathrm{~min}$. Debris was pelleted by centrifugation at $4^{\circ} \mathrm{C}$ for $15 \mathrm{~min}$, and genomic DNA present in the supernatant was removed and precipitated with 0.6 vol. isopropanol. The DNA was recovered by centrifugation, washed with $70 \%$ ethanol, dried at $55^{\circ} \mathrm{C}$, and resuspended in $50 \mu \mathrm{l}$ of React 2 buffer (GIBCO) by heating at $70^{\circ} \mathrm{C}$ for $15 \mathrm{~min}$. After cooling to room temperature, another $50 \mu \mathrm{l}$ of React 2 buffer was added, together with 10 units of EcoRI, and the tube was placed at $37^{\circ} \mathrm{C}$ for $3-4 \mathrm{hr}$. Digestion was halted by heat-inactivation at $70^{\circ} \mathrm{C}$ for $15 \mathrm{~min}$, and after cooling to room temperature ligation was initiated by adding an equal volume of $2 \times$ modified ligase buffer $(10 \mathrm{mM}$
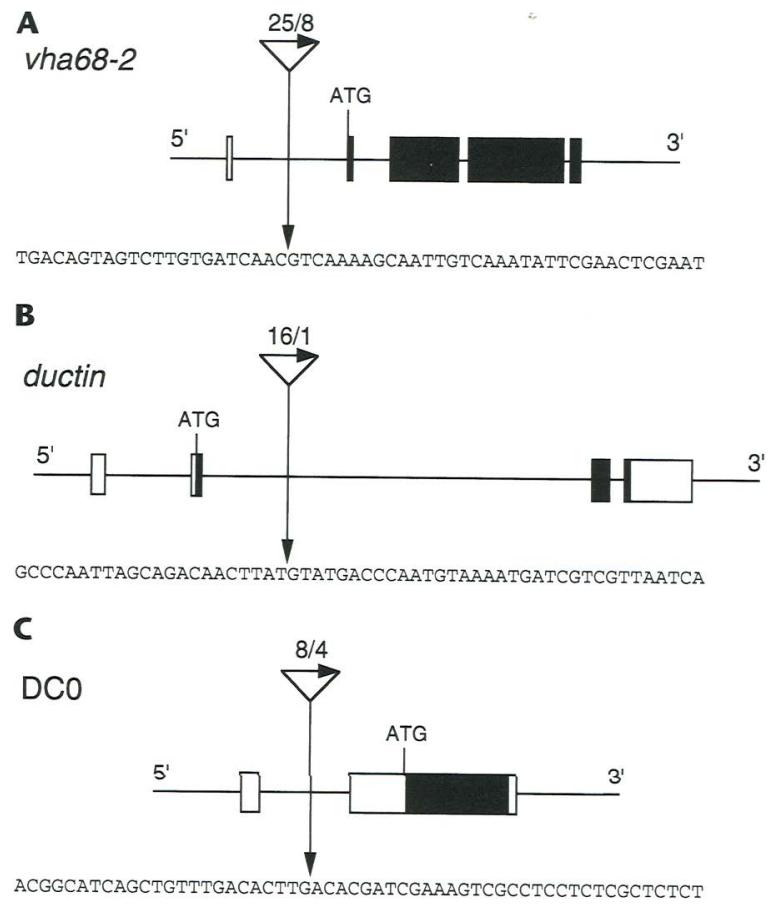

$1 \mathrm{~kb}$

Figure 7 Exact locations of $\mathrm{P}[\mathrm{lacW}]$ insertions in each of the three lines. $(A)$ Insertion in vha68-2 (GenBank accession no. U59147); (B) insertion in ductin (GenBank accession no. X77936); (C) insertion in DCO (GenBank accession no. X16969). Boxes represent exons, coding regions in black. Arrows indicate the orientation of the $P$ elements (plasmid replicon at head of arrow).

$\mathrm{MgCl}_{2}, 4$ mм ATP, 20 mм DTT, 30 mm Tris-HCl pH 7.4) and $0.5 \mu \mathrm{l} \mathrm{T} 4 \mathrm{DNA}$ ligase (Promega; $3 \mathrm{U} / \mu \mathrm{l}$ ).

Competent Escherichia coli (DH5 $\alpha$ or XL1-blue) were prepared using an $\mathrm{RbCl}$ method (Hanahan 1985). Competent cells $(200 \mu \mathrm{l})$ were mixed with $40 \mu \mathrm{l}$ of ligated DNA, placed on ice for $15 \mathrm{~min}$, heat-shocked at $42^{\circ} \mathrm{C}$ for $90 \mathrm{sec}$, again placed on ice for $5 \mathrm{~min}$, and then mixed with $0.5 \mathrm{ml}$ of $2 \times$ YT broth. The culture was shaken at $37^{\circ} \mathrm{C}$ for $1 \mathrm{hr}$, diluted into $25 \mathrm{ml}$ of $\mathrm{LB}$ containing ampicillin at $150 \mu \mathrm{g} /$ $\mathrm{ml}$, and then shaken overnight at $37^{\circ} \mathrm{C}$. Approximately $80 \%$ of overnight cultures showed evidence of growth. One $\mathrm{ml}$ from each $25 \mathrm{ml}$ culture was stored at $-70^{\circ} \mathrm{C}$ in the presence of $20 \%$ glycerol. As a check on contamination, plasmid DNA isolated from $50 \mu \mathrm{l}$ of sampled overnight cultures was characterized by gel electrophoresis.

The remainder of the overnight culture $(24 \mathrm{ml})$ was mixed with cultures representing nine other $P[l a c W]$ lines, and plasmid DNA was prepared by the alkaline lysis method. In all, 184 pools of ten plasmids were generated, each resuspended in $1 \mathrm{ml}$ of TE. Portions of each pool were then mixed to create 19 pools of 100 plasmids. The pools are stored frozen until required for screening. Just $5 \mu l$ of each pool of 100 is sufficient for visualization by agarose gel electrophoresis (Fig. 2), and after blotting to Hybond N 
PLASMID RESCUE OF IHE DROSOPHILA SECOND CHROMOSOME

Table 1. Results of Screening with 27 Independent Target Genes

\begin{tabular}{|c|c|c|c|c|}
\hline Target gene & $\begin{array}{l}\text { Accession } \\
\text { no. }\end{array}$ & $\begin{array}{l}\text { First } \\
\text { round }\end{array}$ & Verified & Reference \\
\hline vha68-2 & U59147 & 3 & 3 & This paper \\
\hline ductin $^{\mathrm{a}}$ & X77936 & 2 & 2 & This paper \\
\hline$D C O^{\mathrm{a}}$ & $\times 16969$ & 6 & $1^{\mathrm{b}}$ & This paper \\
\hline Pp2A-28D & X55199 & 1 & 1 & $\begin{array}{l}\text { H.A. Snaith, C.G. Armstrong, Y. Guo, K. Kaiser, } \\
\text { and P.T.W. Cohen (unpubl.) }\end{array}$ \\
\hline$K L P-38 B$ & & 7 & 7 & $\begin{array}{l}\text { L. Alphey, L. Parker, G. Hawcroft, Y. Guo, } \\
\text { S. Elledge, K. Kaiser, D.M. Glover, and } \\
\text { G. Morgan (unpubl.) }\end{array}$ \\
\hline Syb & L14270 & 2 & $1^{\mathrm{c}}$ & $\begin{array}{l}\text { B. McCabe, Y. Guo, S. Sweeney, E. Goldstein, } \\
\text { K. Kaiser, and C. O'Kane (unpubl.) }\end{array}$ \\
\hline CalpA & Z46891 & 2 & 2 & P. Rosay, Y. Guo, and K. Kaiser (unpubl.) \\
\hline vha14 & Z26918 & 1 & $0^{c}$ & Guo et al. (1996) \\
\hline 19 others $^{d}$ & & 0 & 0 & \\
\hline \multicolumn{5}{|c|}{$\begin{array}{l}\text { aCenes for which P-element insertions have been described previously (Skoulakis et al. 1993; Finbow et al. 1994). } \\
\text { "Only one of the six putative insertions was chosen for further subdivision. } \\
\text { "One first-round hybridization signal was a "cocloning" artefact. } \\
\text { "No first-round signal. }\end{array}$} \\
\hline
\end{tabular}

(Amersham) for hybridization with gene-specific probes (Figs. 3A, 4A, 5A).

See Ashburner (1989) and Lindsley and Zimm (1992) for general Drosophila methods and nomenclature. Recent overviews of P-element methods are provided by Kaiser et al. (1995) and Sentry and Kaiser (1995).

\section{DISCUSSION}

The strategy we have described permits rapid identification of mutant lines corresponding to specific cloned genes. This is illustrated by Figure 3 , detailing the identification of a line with a Pelement insertion in the gene for subunit $A$ of the Drosophila vacuolar ATPase. Three novel and important features of our strategy are as follows. First, we carried out plasmid rescue independently for each of many lines. Plasmid rescue from pools of lines (e.g., Hamilton et al. 1991) leads to misrepresentation both because transformation efficiency varies with the size of rescued plasmid, and because it is difficult to avoid competitive growth. By allowing each transformant to grow independently we avoided misrepresentation and were able to generate sufficient plasmid DNA for screening with any number of target genes. Second, unlike previous examples of SSM by plasmid rescue, the lines described here were generated with the intention of creating and maintaining only lethal insertions of $\mathrm{P}[\mathrm{lacW}]$ (lethals represent only a small proportion of all P-element insertions). Though homozygous chromosomal lethality turned out to be associated with P-element insertion in only approximately half of the lines, even nonlethal insertions can be useful for secondary mutagenesis. Third, there is a commitment to maintain the entire collection of balanced lethal lines in Szeged for the conceivable future. This is unlike most previous site-selected mutagenesis experiments, in which lines were discarded soon after screening, and were thus unavailable to the wider research community.

Approximately one in four cases of screening with cDNA probes has proved successful. cDNA probes will often fail to detect an insertion in a target gene, merely because the rescued plasmid contains no transcribed sequences. Such occasions will arise when an EcoRI site lies between the transposon and the nearest exon. It would of course have been preferable to rescue each line using a range of different enzymes, and to rescue DNA on both sides of the transposon. This would have been prohibitively laborious, however. A simpler way to increase the probability of a hit is via screening with genomic DNA fragments representing nontranscribed in addition to transcribed sequences (though not a fragment that contains repetitive DNA sequences). 


\section{GUO ET AL.}

Even so, one should not expect all second chromosome genes to be represented by $\mathrm{P}[\mathrm{lacW}]$ insertions within the Szeged collection because: (1) $\mathrm{P}[$ lacW $]$ mutagenesis was not carried out to saturation; (2) not all Drosophila genes are good targets for P-element insertion; and (3) not all Drosophila genes correspond to lethal complementation groups. Where a pre-existing mutation cannot be found, it may prove fruitful to probe with genomic DNA more distant to the gene of interest, and thereby detect an insertion in a nearby gene. Such an insertion could be used for local jumping, an elevated rate of transposition within $100 \mathrm{~kb}$ or so on either side of a donor $P$ element (Tower et al. 1993; Zhang and Spradling 1993).

Once one has obtained a line with a single $\mathrm{P}[\mathrm{lac} W]$ transposon within the gene of interest, it is necessary to verify that the insertion is indeed the cause of the mutant phenotype. Spontaneous recessive lethal mutations are common within Drosophila populations, and can become fixed on the same balanced chromosome as a P element. It is thus essential to demonstrate, as for the vha68-2 insertion, that remobilization of the inserted transposon can lead to reversion of the phenotype. Even then it may not be a simple matter to deduce, just from a single allele, the precise role of the gene and its product in Drosophila development or physiology. Remobilization can also result in imprecise excision, however, and thus generation of a range of new alleles of varying severity (e.g. Klambt et al. 1992). The presence of an eye color marker (white) on $\mathrm{P}[\mathrm{lacW}]$ makes loss of the transposon easy to score. Further, P[lacW] was designed as an enhancer-trap element, the lac $Z$ component serving as a reporter for gene expression in the vicinity of the insertion site (Bier et al. 1989). The pattern and timing of $\beta$-galactosidase expression may provide useful information concerning the tissue-specificity and developmental regulation of gene expression.

The collection of P-element lethals generated by Török et al. (1993) is finding many uses in Drosophila genetics and genome mapping. As described here, it provides a simple means of correlating a cloned Drosophila gene with a mutant phenotype. Sufficient plasmid DNA has been prepared to allow screening for many targets. An added dimension would be provided by performing large-scale correlations of cDNA library clones with the Szeged lines. This would provide access to many as yet unknown, but nonetheless essential, Drosophila genetic loci.

\section{ACKNOWLEDGMENTS}

This work was supported by grants from the UK Biotechnology and Biological Sciences Research Council, and from the Human Frontiers Science Programme. We thank Joyce Moore for comments on the manuscript.

\section{REFERENCES}

Ashburner, M. 1989. Drosophila: A laboratory handbook. Cold Spring Harbor Press, Cold Spring Harbor, NY.

Ballinger, D.G. and S. Benzer. 1989. Targeted gene mutations in Drosophila. Proc. Natl. Acad. Sci. 86: 9402-9406.

Bier, E., H. Vaessin, S. Sheperd, K. Lee, K. McCall, S. Barbel, L. Ackerman, R. Caretto, T. Uemura, E. Grell, L.Y. Jan, and Y.N. Jan. 1989. Searching for pattern and mutation with a P-lacZ vector. Genes \& Dev. 3: $1273-1287$.

Das, L. and R. Martienssen. 1995. Site-selected transposon mutagenesis at the HCF106 locus in maize. Plant Cell 7: 287-294.

Finbow, M.E., S.F. Goodwin, L. Meagher, N.J. Lane, J. Keen, J.B.C. Findlay, and K. Kaiser. 1994. Evidence that the $16 \mathrm{kDa}$ proteolipid (subunit $\mathrm{c}$ ) of the vacuolar $\mathrm{H}^{+}$-ATPase and ductin from gap junctions are the same polypeptide in Drosophila and Manduca; Molecular cloning of the Vha16k gene from Drosophila. J. Cell Sci. 107: $1817-1824$.

Guo, Y., K. Kaiser, H. Wieczorek, and J.A.T. Dow. 1996. The Drosophila melanogaster gene vha14 encoding a 14 $\mathrm{kDa}$ F-subunit of the vacuolar ATPase. Gene 172: 239-243.

Hamilton, B.A. and K. Zinn. 1994. From clone to mutant gene. In Drosophila melanogaster: Practical uses in cell and molecular biology (ed. L.S.B. Goldstern and E.A. Fyrberg), pp. 81-94. Academic Press, San Diego, CA.

Hamilton, B.A., M.J. Palazzolo, J.H. Chang, K.V. Raghavan, C.A. Mayeda, M.A. Whitney, and E.M. Meyerowitz. 1991. Large scale screen for transposon insertions into cloned genes. Proc. Natl. Acad. Sci. 88: $2731-2735$.

Hanahan, D. 1985. Techniques for transformation of $E$. Coli. In DNA cloning (ed. D.M. Glover), Vol. 1, pp. 109-135. IRL Press, Oxford, UK.

Kaiser, K. and S.F. Goodwin. 1990. "Site-selected" transposon mutagenesis of Drosophila. Proc. Natl. Acad. Sci. 87: 1686-1690.

Kaiser, K., J. Sentry, and D. Finnegan. 1995. Eukaryotic 


\section{PLASMID RESCUE OF THE DROSOPHILA SECOND CHROMOSOME}

transposable elements as tools to study gene structure and function. In Mobile genetic elements (ed. D.J. Sherratt), pp. 69-100. IRL Press, Oxford, UK.

Kalderon, D. and G.M. Rubin. 1988. Isolation and characterization of Drosophila cAMP-dependent protein kinase genes. Genes \& Dev. 2: 1539-1556.

Klambt, C., L. Glazer, and B.Z. Shilo. 1992. Breathless, a Drosophila FGF receptor homolog, is essential for migration of tracheal and specific midline glial cells. Genes \& Dev. 6: 1668-1678.

Lindsley, D.L. and G. Zimm. 1992. The genome of Drosophila melanogaster. Academic Press, San Diego, CA.

Rushforth, A.M., B. Saari, and P. Anderson. 1993. Site-selected insertion of the transposon Tc1 into a Caenorhabditis elegans myosin light chain gene. Mol. Cell. Biol. 13: 902.

Sentry, J.W. and K. Kaiser. 1995. Progress in Drosophila genome manipulation. Transgenic Res. 4: 155-162.

Skoulakis, E.M.C., D. Kalderon, and R.L. Davis. 1993. Preferential expression in mushroom bodies of the catalytic subunit of protein kinase $A$ and its role in learning and memory. Neuron 11: 197-208.

Spradling, A.C., D.M. Stern, I. Kiss, J. Roote, T. Laverty, and G.M. Rubin. 1995. Gene disruptions using $P$ transposable elements: An integral component of the Drosophila genome project. Proc. Natl. Acad. Sci. 92: 10824-10830.

Török, T., G. Tick, M. Alvarado, and I. Kiss. 1993. P-lacW insertional mutagenesis on the second chromosome of Drosophila melanogaster: Isolation of lethals with different overgrowth phenotypes. Genetics 135: 71-80.

Tower, J., G.H. Karpen, N. Craig, and A.C. Spradling. 1993. Preferential transposition of Drosophila P elements to nearby chromosomal sites. Genetics 133: 347-359.

Zhang, P. and A.C. Spradling. 1993. Efficient and dispersed local P element transposition from Drosophila females. Genetics 133: 361-373.

Zwaal, R.R., A. Broeks, J. Vanmeurs, J.T.M. Groenen, and R.H.A. Plasterk. 1993. Target-selected gene inactivation in Caenorhabditis elegans by using a frozen transposon insertion mutant bank. Proc. Natl. Acad. Sci.

90: 7431-7435.

Received April 19, 1996; accepted in revised form July 26, 1996. 


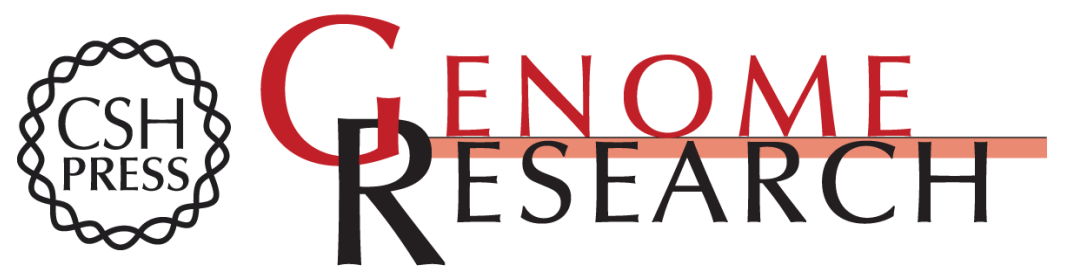

\section{Site-selected mutagenesis of the Drosophila second chromosome via plasmid rescue of lethal P-element insertions.}

Y Guo, A Gillan, T Török, et al.

Genome Res. 1996 6: 972-979

Access the most recent version at doi:10.1101/gr.6.10.972

References This article cites 17 articles, 14 of which can be accessed free at:

http://genome.cshlp.org/content/6/10/972.full.html\#ref-list-1

\section{License}

Email Alerting Receive free email alerts when new articles cite this article - sign up in the box at the Service top right corner of the article or click here.

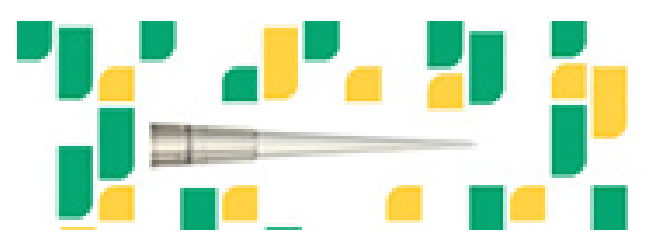

To subscribe to Genome Research go to: https://genome.cshlp.org/subscriptions 